\title{
ゴしと人生
}

\section{古川淳 二*}

\section{1. ま $え$ がき}

研究哲学について先輩の先生方が書かれることになり 私にも機会が与えられた．名誉なことではあるが困って いるのが現状である．私の場合は今まで確固とした研究 哲学などあったわけでなく，ただひた走りに何かをやっ てきたのであって，気がついてみたら停年になっていた といらだけである. しかし，昭和12年に京大を卒業して 40年近くも京大にいたので思い出がないわけではない. 私の場合は幸か不幸加合成ゴムの研究一筋にやってきた ので，後で考えると成功のときはもちろん，失敗のとき もそれなりの意味はあったように思われる.これらをた どってみて私の研究とは何だったかを記してみたい. 同 ヒストーリーについて他にも書いたので,ここでは書き 残したことをつけ加えてみたい．

\section{2. 合成ゴムとの出逢い, 戦時中の研究}

私の研究のことを書く前に，化学との出逢いのことを 思い出してみたい，私は化学上りも科学に憧れていた。 幼くして父を亡くした私は，母と病んだ兄との三人暮し であった．兄は私からいらのも抗こがましいが，科学一 のすばらしい才能を持っていたよらに思5．病魔に侵さ れ，中学もいけず, 講義録の独学で旧制中学の検定試験 を全科目一回でパスしたほどである。飛行機や電車の模 型を作ったり，天体望遠鏡などを手がけたりした．私は 物心ついてからその影響を受けていたに違いない，科学 こそ我が生涯の仕事だといつの間にか思い込むようにな っていった

しかし，商業学校へ入ってしまった．商都大阪にいて， 母罗何となしに私を商業学校へ入れてしまったのであ る. 私には何でも面白かったが，だんだん高学年になっ てみると，学校がいかにもつまらないことに気がついた が，とき既に遅しである。しかし，同僚の中に同じよう な考えのものが二人いて，旧制高校を志願してみようと
いうことになった．当時，商業中学からは旧制高校へい くのは大変で, 私の学校でも例がなかったので苦労した わけである. 英語, 国語はともかくとして代数, 幾何はず いぶん程度が低かったので苦労した．最終学年では商業 の講義を聞いていても，落で数学の解答を考えていた.

姫路旧制高校へ入れたときの喜びはひとしおであっ た. 閏くこと学ぶことすべて新鮮で，はじめて学問の面 白さを知りはじめた。しかし，卒業間際になってまた迷 いはしめた. はじめ，医科へ進もうとして理科乙類(ド イッ語，動植物専攻)へ入り，植物，動物の講義を開い ているらちに，またつまらなくなった，動物，植物はや たらに記憶することが多く，考える学問でないことに気 がついたからである. 化学を選んだのは一つの妥協であ った. 物理をやるには数学は弱いし，そらかといって何 か人に勝てるようなものはないかといらと，人のあまり やらないことをするしかない，化学を選んだのは兄が薬 専人入学して亡くなったからかもしれない，京大の工業 化学科へはいったのだが，半年もしないうちにまたいや になり出した，分析の実験をやっているらちに，化学も 理論科学ではないと思いはじめたのである.しかし，も うどらすることもできないと自分で勉強しはじめた，有 機電子論や，永海佳一郎先生の「無機化学の基礎」を読 んでいるらちに，何となくやれそうた゚と思いはじめた。 エッゲルトの物理化学やカーラーの有機化学のドイッの 原書なども買って読みはじめた。これが化学との出逢い

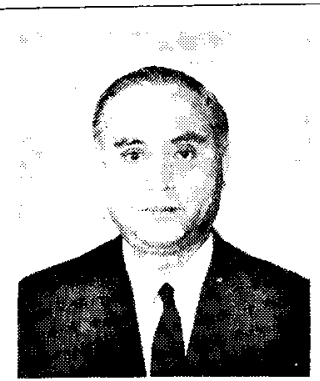

* 自宅 (厂227 神奈川県横浜 市緑区青葉台2-29.JSR 社 宅2-103)東京理科大学教授. 愛知工業大学教授. 京都大学 名誉教授. 工博. 昭和12年京 都大学工学部卒業, 同大助手, 講師, 助教授を経て昭和23年 同大化学研究所教授. 昭和 51 年退官後現職。専門は高分子 化学. 本会前会長. 〈趣味> 絵面鑑賞，思索 
であった.

こらしてみると私の科学への憧れといっても他愛もな いもので，いつも私の心は摇れ動いていた，そしてこれ からむ摇れ動いていくのである．大分前固きが長くなっ たので合成ゴムを選んだいきさつを述べてみよう，

合成ゴム人の関心は，ドイッの雑誌に現われたブナ $\mathrm{S}$ ，ブナNの記事であったが，私が合成ゴムの研究をは じめた直接の動機は，帝国発明協会の悬賞募集であっ た．卒業間際で卒論を書き上げていたころであったが， 恩師喜多先生からやってみよといわれた，卒論は当時ド イッからきていたカール・ラウェル先生でナフタレンの 反応に及ぼす溶媒効果の研究であった，塩素化が溶媒に よって変わるのはナフタレンが会合しているからである との想定で，ナフタレンの会合を紫外スペクトルから調 べた，発光装置やスペクトルのキュベットなど手作りで くったた. 赤外, NMR もない時代で, 紫外スペクトル もその解釈はまだわからないころのことである。溶媒を 変えても別にシフトが起こるわけでなかったので，その 旨，報告を出したが，先生の意見とは違うとあまり御機 嫌はよくなかった，そこへ喜多先生から，合成ゴムをや れとの括があり，ラウェル先生の括宅入夜分 5 かが い,片言のドイツ語で合成ゴムをやらせてほしいと頼み こんだ.しかし返事は“ナイン”で，理由は合成ゴムの 研究などはとても一人でやれるよらなものではないとい らことである。乙して代わりに，パラフィンの空気酸化 により脂肪酸をつくるのは面白いからやってみてはとい われた，喜多先生に相談すると，日本には油脂の資源は 当時不足はなかったので䭾目だといわれ板ばさみにな りラウェル先生には隠れて合成ゴムの研究をやること になったが，先生の御機嫌はますます悪くなっていった よらである。

卒業してからは本格的に合成ゴムの仕事に取組むこと になるが，さて合成ゴムといっても何をどらしてやるの かわからない，当時，アメリ力にはdu Pont 社の Carothers 博士がクロロプレンゴム（当時 Duprene，後 Neopreneと改名) があり，一方ドイッではブナN，ブナ Sが発表されていた，人の真似をやるわけにもいかない ので喜多先生に伺ったが，それはお前が考えよというこ とで困りぬいたあげく思いついたのは，アセチレンから ビニルアセチレンをつくり，これを部分水素添加してブ タジェンをつくる方法で，これなら当時の資源から可能 だし，ドイッの方法より簡単だといらことである，最も ドイッの方法はよくわからなかったが，多分アセチレン

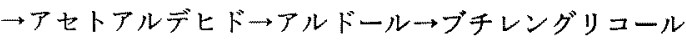

フフタジェンの 4段法だと思われたが,これは後になっ て4段法が発表された. ビニルアセチレンは Carothers がクロロプレンをつくるときの中間原料で, 塩化銅一塩 化アンモン水溶液にアセチレンを通して得られるので, これを部分水添して簢単にブタジェンにできると思った のであるが，さてやり出してみると大変な仕事であるこ

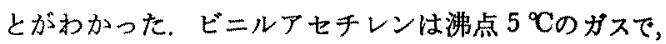
反応率が10\%ぐらいで低いので，これをアセチレンガス からら捕集するにはー70Cぐらいに泠やさねばならない。 そのらえ爆発性のジビニルアセチレンが副生する，とう してもガラス器具の実験だけでは無理とわかり，徝櫭术 ンプやいろいるの設備を買ってもらわねばならず，それ に当時ドライアイスは神戸の日本水産まで買いにいか子 ば手にはいらない，メンバーは学生の中村正三君と二人 なので，ドライアイスを買らとそれが解けるまで何日も 徹夜で実験した，そしてやっと半年経ってピニルアセチ レンをつくり，まず手はじめにそれからクロロプレンを つくるのに成功した. Carothers の研究の真似に成功し たのである、そしてこれから部分還元してブタジェンに するのであるが，これがまた大変だった．当時，部分被 毒したニッケル触媒で，アセチレンかららチレンをつく る研究がありこれを育用してみたが，ビニルアセチレ ンからはブテンになるばかりであった. ブタジェンはフ セチレン以上に，還元されやすく，ブテンまで進んでし ま5のである。1 年以上は徒労の実験が䋨いた。当時,

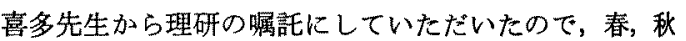
2 回上京して報告にいかねばならず苦脳の日が続いた。 亜鉛粉末一アルカリ水溶液一塩化鉄系の僄元昘を見つけ るには 1 年半もかかった. 塩化鉄を加えると要鉛粉末上 に沈殿し局部電池が形成，還元がスムーズに進み，100\% に近い収率でブタジェンのみになる。これを加えないと 分子状の水素がどんどん出るので加圧釡が危険になる。 ブタジエン中に含まれるビニルアセチレンは徽量であっ ても，完全に除かないと重合の有害不純物となるので， その除去に苦労したが，これもアンモニア性塩化銅水溶 液で洗うとブタジェンは錯化せず，ビニルアセチレンの み沈殿してくることもわかった。このような苦労は書け ば，きりがないが，やはり若かかったためであろらか， 徹夜を繰りかえしても堪えることができた，

この仕事はその後, 時局の切迫で高柣の化学研究所棈 内に試験工場をつくるところまで進んだが，住友化学の 隅谷威雄氏が大勢の工場員を率いて乗りこんでくれたの で，昭和17年に日産 200 キロのプラントが完成し，これ を運転することができた（図1～3），增尾富士雄，川田 


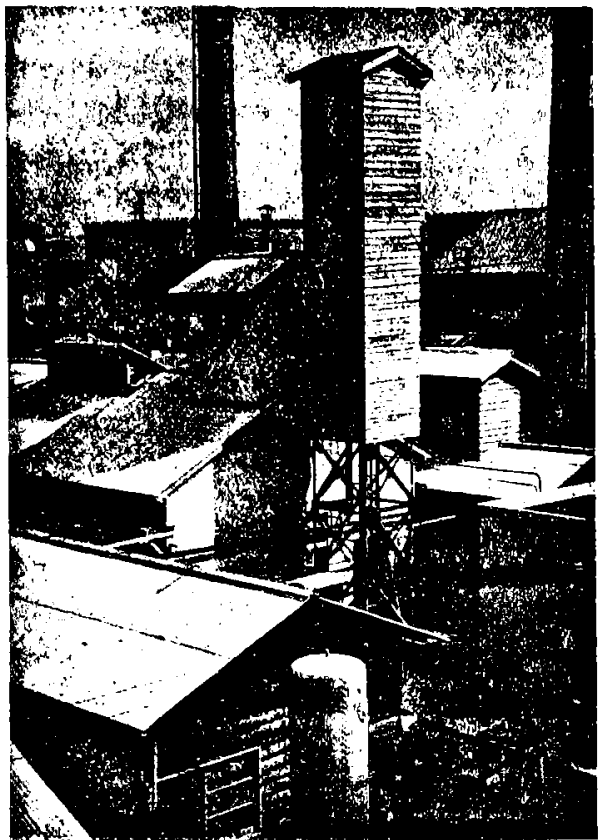

合成ゴム工場全景にして，モノビニルアセチレ ン製造室, 同捕集室, ブタジエン製造室, 同貯 蔵室, 重合室の他, 倉庫ボイラー室, 給水室を 加えても建坪100坪くらいで日産 $50 \mathrm{~kg}$ の工場と しては他法のごとき広大な面積を要しない.

図 1 合成ゴム工場（京大化学研究所・高槻実験工 場全景. 1943年当時)

茂，塚本正氏らが当時研究者として参加され，大メンバ 一であった. その後, このプラントは新居浜の住友化学 に移され,終戦までに 3 トンのニトリルゴムがつくられ， 軍用に供せられた. 研究室ではメチルビニルケトンをビ ニルアセチレンと水との反応からつくりこれとブタジ エンとを共重合し，ニトリルゴムに匹敵する耐油性をむ ち，しかも可塑性のよい合成ゴムを発明，これを帝国発 明協会に提出，見事 1 万円の賞金を獲得したのは，昭和 19年の初めであった. 思えば研究を始めて6 年であっ た. その間，いろいろの体験をした. 化学工学の勉强む したし，機械設計の計算，資材の計算など大学の研究室 としては苦労した，共重合の理論にも興味をるったが, 応用研究のほ5に忙しかった. しかし、このよ5な苦心 談は会社の研究なら当たり前のことで，あまり自慢にな るよらなことではない，私にとって得た教訓は，研究は どらしてやるかといら体験であった. 何よりも，何を研 究の対象に選ぶかが，研究の成功の踺だといらことであ る.これが的を外れていなければ，後は努力と若さで何

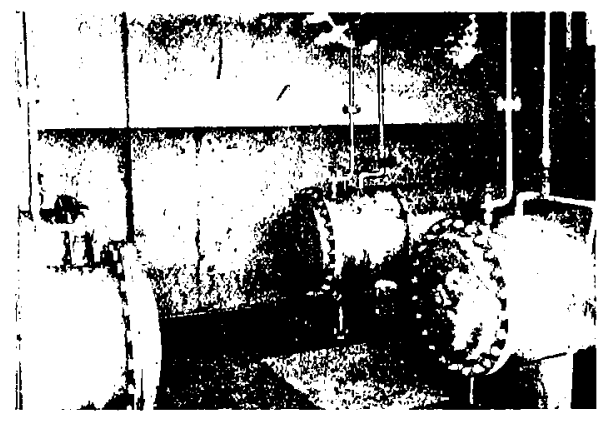

モノビニルアセチレン貯槽. 一台内容約 $300 l$ を 有し，装てん，取出しはすべてバルブの開閉に より遠方まで液体モノビニルアセチレンとして 輸送される。

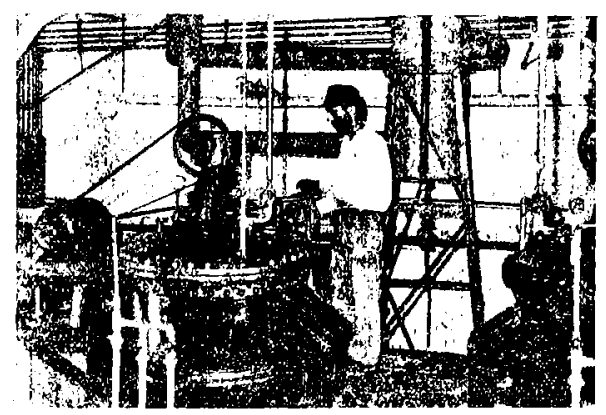

プタジエン製造用還元缶 液体モノビニルアセ チレンは本工場独特の活性化覀鉛により収率, 純度とすに $100 \%$ のブタジェンとなる，中央の 計量器より液化モノビニルアセチレンは容量 $700 l の$ 中圧還元仵に装入せられ数時閒にて完全 に $100 \%$ のブタジェンとなる．還元に使用せら れた亜鉛泥は底部より抜きとられ，電解法にて 容易に再生せられ, 直ちに次回の還元に用いら れる.

図 2 ブタジェン製造設備(人物は筆者)

でもできるといらことである，戦時中の食糧事情で，肉 片にありつくのもまれではあったが，いただいても私に はゴムの塊りに見えた．よく身体が続いたものたと思 5 .

私にとって合成ゴムはゴム研究のはじめであり、これ が生涯の仕事一と続くのである.ゴム協会のお世話にな ったのも，私の人生にとって大きい影響を与えた. 研究 を始めるに当たって大阪工業試験所の角谷清明博士を訪 ねた. 既に同所はアルコール法のブタジェンゴムをつく っておられ，また同氏は京大の大先輩でもあった．同博 士から親切に研究の注意すべき点を教えていただいた。 東工大の神原教授を訪問したのも同しころである. 先生 は合成絨維の研究で既にポリアクリル酸から優れたもの 


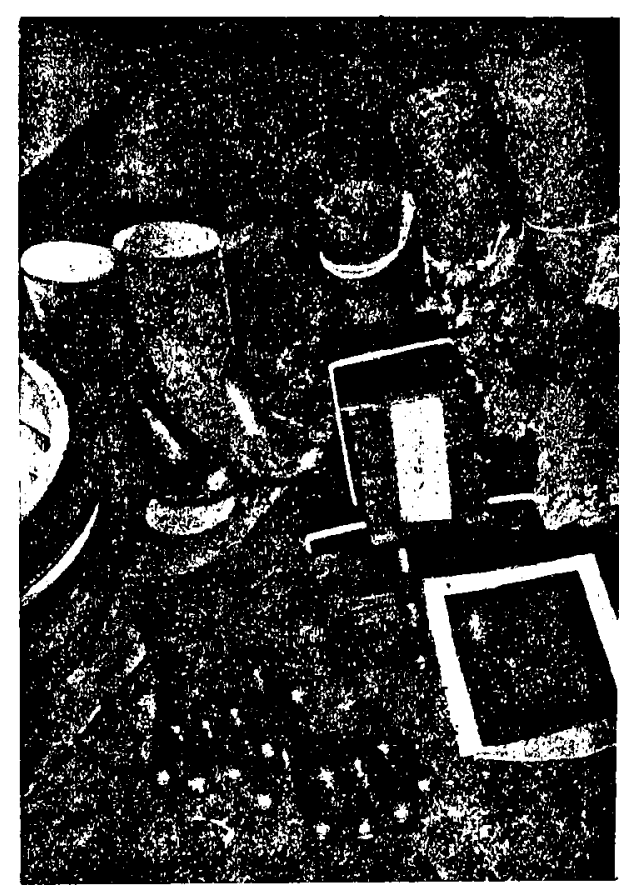

合成ゴム製品. かくして耐油性, 耐熱性, 耐老 化性に损いて優秀なる生ゴムが得られ，これよ り航空機用耐油パッキング，耐油ホース，工業 用手袋等はもち論, その他特殊兵器の主要部分 として使用される。

図 3 合成ゴム製品の一部

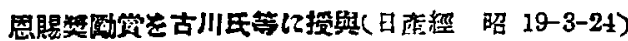

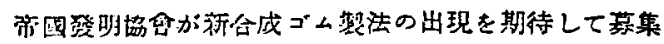

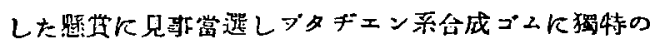
技法走拓いた京大化學研究所古川㵏二博士外 6 名に

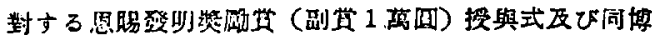
土の研究發表會は 23 日午後 2 洔牛から神田學士鼻

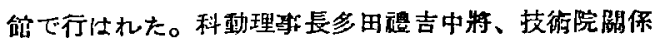

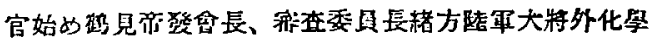
别保研究考等䄪 40 名出席、表新式に次い:で同博士は 研究の大略特に闹法がプダェン柔ししては若しくエ

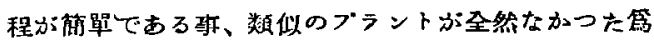
工業化に芦笭した承等を物語り僡衆に多大の感銘を與 $\sim \hbar_{0}$

図 4 合成ゴム奬賞を伝えるゴム協会の記事（日本 ゴム協会誌，17，272(1944))

をつくっておられたが，合成ゴムもチオコール系の新し い研究を始めておられた. デシケーターの中の大きなゴ ムの塊りを見せていただいた，先生は当時田中芳雄先生 の助教授をしておられ，学術振與会の合成ゴム部会の幹
事としても我々を指導されていた. 先策とは有難いもの で，特にゴム協会では我か後輩のためにどんなに尽くさ れたかは身にしみて感ぜられた，当時海軍におられた国 沢 新太郎氏や，小川若 三郎氏，小室 経治氏，山崎 武二 氏，遠藤英麿氏，小出武城氏，茌林伍郎氏，大北忠男氏 ら数えあげると次々と先輩の顔が浮かぶ. 九大の君島武 男先生, 東大の田中芳雄先生からも激励のお言葉をいた だいた. ヨ゙ムの研究に一生を捧げよらといら私の決心 は,こ5して育っていったよ5に思5。私はゴム協会に はこの动統が伝わっており，これを伝えていかねばなら ないと思っている. ヨ゙ム協会の家族的愛情は，戦後の荒 廃の中の救いであった. 関西支部です加藤義信氏が中心 で，見学会に招いていただいたことは忘れられない. 大 内新興化学の大内隼人氏，山本義之氏，天満サブの横井 氏, 坂井化学の坂井氏らが学会の我々を助けていただい たことは，私の研究生活の支えとなった．富久宏太郎氏 と研究した簡易可塑度計や金子東助氏と考案した加硫計 算尺の研究に，島津製作所の明石好光氏が示された協力 は有難かった，そして私の退官まで，私のコムム研究を 支えて下さった東洋ゴムの富久力松社長の御厚意は，生 涯忘れることができない.そしてブリヂストンの方々と の長い共同研究へと, 私の第二の合成ゴムの研究は進ん でいくのである。

\section{3. 有㭖金属触媒の研究}

戦後の混乱期は, 新しい研究に取り組むのは物心両面 で困難であった. 合成ゴムの研究は米軍によって禁止さ れた. るっともやろうと思っても資材はないし,精神的に も樑い絶望感のもとで意欲も涌いてくるものではない. 研究費を稼ぐためにサッカリンの合成などをやる研究室 むないではなかったが，私にはそんなことまでするのは 心をみじめにするだけだと思った。 こんなときにはひた すら勉強するに限ると思い，幸い大阪の米軍の文化セン ターが開放され, 海外の雑誌, 文献が泉のよらにはいっ てきたので日参しむさぼるよらに読みまくった. Flory のゴム弾性論, Reppe のすばらしいアセチレン合成化 学，それを米軍がまとめた PB レポートなど天国で遊ふ 思いであった，レッぺ反応でビニルエーテルが简単にで きるので，それを原料にして新しい合成をやろ て、コハク酸イミドと反応させ，容易にビニルコハク酸 イミドができることを見出し，これは大西章君の学位論 文になった. J. Org. Chem. にも投稿した. 復員で引き 上げてきた富久宏太郎君の研究では，たまたまウイリア ムスの可塑度計が残っていたので，可塑性の研究をはじ 
めたが，これも同君の学位論文になった．昭和23年には 桜田研究室の教授にしてもらったので，何か手伝ら研究 はないかと思い，同研究室の中心課題である酢酸ビニル の気相合成に取り組んだ、気相反応を徹底的に解析した が，気相反応の通例である反応温度の不均一分布をなく するため，迴転式反応炉を考案し，パイロットプラント までつくった：これはセメントのロータリーキルンのよ らに，触媒粒子を入れてガラガラ回転するやり方で，大 前劦君の学位論文になった。助教授の小䈎英夫君にも手 伝ってもらってパイロットプラントを動かしたが,これ 性戦時中の体験もあって苦労もなく行らことができた そうこらする5ちに，アメリカの UOP で流動触媒が発 表され，米軍文化センターでその内容を知ることができ るようになった，触媒粒層に反応がスを下から吹きこん でいくと層がふくらみ，やがて触媒粒子が液体分子のよ らに流動し出寸のである，反灾温度はむちろん均一にな るし，装㯰は簡単である，ちょうどその頃京大化学工学 科のクラスメートの永田進治教授が流動触媒の研究を始 められ，これを䣷酸ビニルの合成に応用しよらとして共 同でパイロットプラントを設計運転した。 これは一時酢 ビ工場に採用された。

しかし，私の興味は流動粉体に向けられた。なぜ，粒 体が液体のよ5に流動するのかである．液体の性質は分 子運動で定り，絶対温度に比例する，そらすれば，流動 粉体でもその粒子の運動の尺度となる絶対温度 $T$ に相当 するものがわかれば，液体と同様の理論が成り立つだろ らと考えた，粒体の運動は吹込むガスの流速によって与 えられるのであるから，流速りを温度の尺度にとってみ ると，見事流動粉体の性質がすべて液体と同じよらに表 現できることがわかった．液体の膨脹は $T に$ 比例する が，粒度粉体の体積は $v$ に比例するし，液体の粘度は $\exp \left(E^{*} / R T\right)\left(E^{*}\right.$ は流動活性化エネルギー)に比例する が, 流動粉体の粘度も, $\exp \left(E^{*} / v\right)$ に比例する。この論 文は大前君上連名でアメリカの Ind. Eng.Chem. 飞投稿 し，かなりの反響があったまた，流動粉体を用いてポ リビニルアルコール瀻維の熱処理に応用し，加熱粉体浴 の日本特許むとったが，これはダンロップ社の粉体浴加 硫法上りも早かったので，同社から特許についての非公 式の交涉むあった.

このよ5にして戦後, 何とか大学らしい需囲気に立ち かえるよらになったが，実はこの頃，敗戦ドイッではチ ーグラー博士がすばらしい仕事をしていたのは知る由も なかった. チーグラーは同じ頃ミュールハイムの石炭研 究所の所長になり，有機リチウムの研究をしていたので
ある.これは彼の戦前の研究の続きであったが，このよ らな純学問的な研究を敗戦後の国立研究所で行った彼の 英断には，頭の下がる思いである，彼はエチルリチウム を蒸溜するとブチルリチウムが少しできることを見出し たのであるが，彼はこのときエチルリチウムが分解して エチレンと水素化リチウムとわかれるとともにこのエ チレンがエチルリチウムに反応してエチレンの 2 量体が できると判断した，てして劇的なポリエチレンの新しい 製法を発見するのである.1955年のことである.この報 告はその後数年して発表され世界を驚嗼させるのであ る、続いてイタリアのナッタ博士がこれをプロピレンの 重合に応用して，立体規則性のポリプロピレンを発見す るに及んで，日本の化学工業会社に一大衝撃を与えるの である、そしてその特許獲得にモンテカチニ社へ殺 到 し，いわゆるモンテ参りが起こる．日本の会社はむちろ 几, 大学の研究所むいち早く, その研究のトレースを始 める．更にそのころ，グッドリッチ社がチーグラ一触媒 を用い，シスポリイソプレンを合成し，遂に天然ゴムと 化学的に同一のものができたのである。

私はそのころ，京大工学部に講座をもっていて，鶴田 禎二氏を助教授に，三枝武夫氏を助手にきてもらって陣 容は充実していたので，有機金属化合物の研究は私達に も極めて魅力的であった. しかし上く考えてみるとチ ーグラーの特許も既に 5 年経っており，今から同じこと を始めても，チーグラーに追いつけるはずがない，何か 変わった事でなけ机いつまでもその後歴を择するだけ だ、をれには有機アルミニウム以外でなければならない と心に決めた，有機金属としては古くからグリニャール 試薬があり，その後有機リチウム，リチウムアルミニウ ムハイドライドがあり，チーグラーはこれから有機アル ミニウムを見つけていったのである。私達はアルキル亜 鉛, ホウ素, 七素, 水銀, カドミウム, アンチモンと他 の有機金属化合物の重合触媒性を謂心゙出したが，オレフ ィンの重合活性はゼロであった. しかし，グリニャール 試薬もオレフィンには不活性で, >C=Oのカルボニル のよらな極性基にのみ付加反応することを考えると，む しろオレフィンよりも極性のビニル化合物や，ェチレン オキシドのよらな極性のモノマーを狙らべきだと気がつ いた. 当時, 私の研究室には井上祥平, 坂田良三, 今井 宏補, 川端成涁, 藤井弘保君ら俊秀が集まってきたので， 活気を带びていた。 やり出してみると面白いほど新しい 重合触媒が続↔と見出された.トリエチルホウ素を塩化 ビニルモ/マーに加えると， $-70^{\circ} \mathrm{C}$ 低温でも重合反応 が起こる. ジェチル刺鉛をエチレンオキシドやプロピレ 
ンオキシドに加えると，極めて高い重合度のポリマーに なる.しかし,ど5も収量にバラッキがあり,やり直して みるとできないこともある，きっとモノマーの精制が悪 いのではないかと，モレキュラーシーブを通してみると 全く重合しない，ひょっとしたら销量に入り込んだ酸素 や水が効いているのではないかと考えるよらになった。 そしてこれを積極的に加えてみると重合は爆発的に起こ り，見事なポリマーが確実に得られるよらになった. ト リエチルホウ素は北量の酸素で過酸化物ができていて, これが塩化ビニルの重合触媒になっていたのである.

$\mathrm{Et}_{8} \mathrm{~B}+\mathrm{O}_{2} \rightarrow\left[\mathrm{Et}_{2} \mathrm{BOOEt}\right] \rightarrow \mathrm{Et}_{2} \mathrm{BO} \cdot+\cdot \mathrm{OEt}$

しかしこれは幸運であった. 中間体の過酸化物がむし安 定だったら，これが蓄積して最後に大爆発を起こしてい たであろら．不安定なため，直ちに分解して重合を引き 起こしていたのである. トリェチルホウ素は水には安定 で，酸素さえなければモノマーと混ぜておいても何も起 こらないので,メチルメタクリレートのポリマーとモ， マーとの混合物に加えて, 缶でシールしたものは速乾性 の塗料になるだろう．午を開けて塗ると直ちに過酸化物 触媒を生じ，残りのモノマーが重合してしま5からであ る.このアイデアは，アメリカの会社で講演に招かれた とき相談を受けたことがある。

ジェチル亜鉛によるプロピレンオキシドの重合む，ま ず水やアルコールと反応して亜雓のアルキル水酸化物

$$
\begin{aligned}
& \mathrm{Et}_{2} \mathrm{Zn}+\mathbf{H}_{\mathbf{2}} \mathrm{O} \rightarrow \mathrm{Et}(\mathrm{ZnO}) \mathrm{nH} \\
& \mathrm{Et}_{\mathbf{2}} \mathrm{Zn}+\mathbf{R O H} \rightarrow(\mathrm{EtZnOR}) \mathbf{n}
\end{aligned}
$$

を生じここれが触媒になる．この重合度が極めて高く， グリシジルエーテルと共重合させると優れたゴムとな る. 折しもこのポリマーを研究していたゼネラルタイヤ 社が，我々の報文を見て特許の譲渡を申し入れてきた。

そして招待を受けて，三枝君と渡米したのが1960年であ った(図 5). 招待といっても連日講演させられ，ハード ワークであったが, よい释験になった，40日の予定を倍

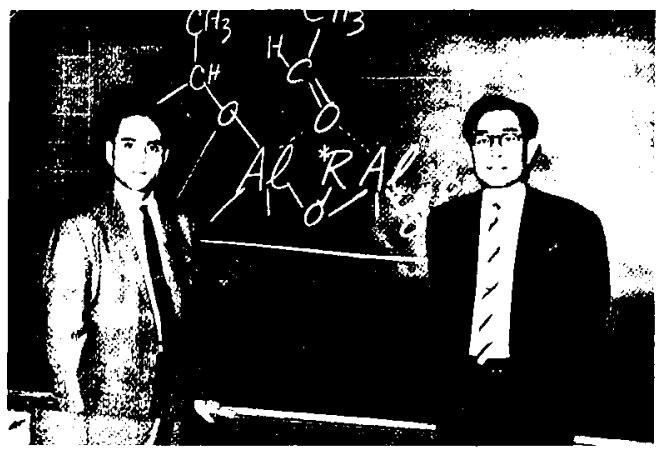

図 5 1960年当时の筆者(左)と三枝武夫氏(右)
に伸ばして、ヨーロッパヘも初めて講演旅行した. ベン シルバニア大の C. Price 教授とも親交を結ふよう.にな ったが, Price教授はその後創設された京大合成化学教室 の最初の招へい教授となられた. プルックリンポリテク の H. Mark 博士，メロン研究所におられた P.J. Flory 教授をはじ，欧米の各社の研究所長とも接することが でき，その後の研究に非常なプラスとなった. その後, 每年カナダ，イギリス，アメリカなど各地の国際会議に 招待され講演にも出かけるよらになった.こうしてみる と，研究上の新しい発見というものはこ5も貴重なるの であるかがわかった。

アセトアルデヒドの重合も偶然の機会に発見した，当 時，ホルムアルデヒドの重合でデルリンがつくられるこ とはすでに発表されていたが，アセトアルデヒドの重合 はほとんどなかった．フランスの石炭研究所の Retort博 士が，アセトアルデヒドをドライアイスで氷結すると， それが融解しはじあるとき重合するという不思議な現 象を見出していたが，触媒による重合は全く報告がなか った. たしか, 東京での学会の帰りに三枝君となせ゚アセ トアルデヒドの重合がないのだろらか，一つやってみて はといら話になった，帰洛して大学院生の藤井弘保君に 実験をやってもららことになったが，水や酸素が前の実 験で重要なことがわかっていたので，今度はアセトアル デヒドを充分脱水精製しておこ5と脱水剤としてモレキ ェラーシーブの中をドライアイスで冷やして通したとこ ろ，簡単にその中で重合してしまった．調べたところ， 分子量が 1 千万近いポリマーであることが判明した．何 のことはない，活性アルミナが触媒になっていたのであ る.この研究も内外の注目を集め，Retort 博士にもその 後招待され，また du Pont 社の Vogl 博士どの親交のき っかけになった. 1960年にアメリカに初めて行ったと き, du Pont 社の招待考受け講演したが，実は同社でも アセトアルデヒドの重合をやっていたのである. リチウ ムアルコラートによる一種のアニオン重合で, 触媒む機 構も異なるものである．我なの配位イオン重合とは異な るが同社む我々の仕事に非常に注目したのである，面白 い話がある，実はもら一人世界でやっていた人がいたの である．有名な Natta 博士であって，これも我々と触媒 が違っていて，トリエチルアルミをつかっていたが,こ れも私達が同時に発見していた.この方法では，ポリブ ロピレンのよらな結晶性のポリマーになる，私達はとも かく報文にして抗こらとドイッの「高分子化学」に投稿 したところ，一部同様の Natta 博士の論文が同じ号に綍 いて出たのである，外国特許も後でわかったが，国によ 
って私達の方が先願になっていたが，トイッでは㝵請の 日が Natta 教授と同じであったが受付時閒のほ5が私達 より Natta 教授の方が早く，特許をとられてしまった。 しかしこのポリマーは熱安定性が悪く，結局ものには ならなかった。

こらしてみると，研究とはともかく世界に先がけて新 しいことをやるといらことが大事である。人の真似をし ていてはいかに立派な仕事でも価值はない，柳の下にど じょらはいても，しょせん小さいどじょうである.大きな 魚は人のない所にいるのであろら，という教訓を得た。

\section{3. シスポリブタジェン}

1960年初めごろから，私達の研究室でシスポリブタジ エンの研究を始めた，当時，すでにチーグラー触媒でシ スポリイソプレンのできることが知られていたが，同じ 触媒でブタジエンを重合するとトランスポリブタジェン しかできない.ブタジェンのシス重合はできないものか といら相談がブリヂストンタイヤ社長の石檽正二郎氏か ら伝わってきた．同社の前田哲郎氏，下里錠次氏がこら れ，さらに石橋幹一郎氏，松平信孝氏，勝本信之助氏ら がわざわざ京大までこられた，お引き受けしてむ，でき るのかどらかわからないので, 大分迷った. 先輩の東洋 ゴムの富久力松氏に相談にいったが，国家的な仕事たか らやりなさいと激励を受けた，小田良平教授から激励さ れ，わざわざ東京のブリヂストンタイヤ本社まで出向い て下った. たとえ，不成功に終ってむよいからといらの でお引き受けすることになった，世界では，チーグラー 触媒の成分にヨウ化チタンを用いるとシスの高いポリブ タジェンができるといらフィリップス法が伝わってきた のは，だふ後であった．原理的にできないのではない かと考えてみたが，その理由が発見できなかった，不安 はあったが, 問題がはっきりしているので, 戦時中の合 成ゴムの研究より気分的に楽であるよ5な気むした．京 大から助手の大西章博士がブリヂストンタイヤに入社 し，大学と会社とで協同して研究を開始した. しかし， アルミの代わりに亜雓を用いたりしていくらチーグラー 触媒をこ执まわても，できるのはトランスポリブタジ エンだけで，1年ぐらいはすぐ経ってしまった．私は当 時既に有機金属触媒を多く手がけていたが，チタン触媒 にオレフィンの水素添加作用のあることに気がついてお り，水素添加と重合との間に何か関係があるのではない 加と思い出した，每月ブリヂストンの研究所（当時戸塚 工場内）に通い，雑誌会でこのことを話したことを覚え ているが，それから間もなく年末から翌年の1月だった
か，京大から入社した松本效君から，ラネーニッケルが わずかではあるがポリブタジェンを与えることそそして それがシスポリブタジエンであることを電話で伝えてき た、それは劇的な一瞬であった。なせなら，ニッケルや コバルトはオレフィンの重合では禁止剂になるといらチ ーグラーの報告があったからである。しかし，ジオレフ ィンでは全く様子が違っていた．その後, ニッケル塩に トリエチルアルミを作用させてできると考えられるアル キルニッケルが極めて偍れたシスポリブタジェンへの触 媒であることがわかってきた. そして分担していた各チ 一ムが続々と新しいニッケル触媒を発見していった．成 功が成功を生むとはこのことであろう，魚は一度漁場を 発見すると塊っているものである，結局，ニッケル塩一 トリエチルアルミニウムーフッ化ホウ素の 3 成分上りな る，ブリヂストン触媒が完成するまでには半年とかから なかった. フッ化ホウ素はアルキルニッケルを錯化安定 化していることも後でわかった.

$$
\begin{aligned}
& \mathrm{NiX}_{2}+\mathrm{Et}_{3} \mathrm{Al} \rightarrow \mathrm{EtNiX}+\mathrm{Et}_{2} \mathrm{AlX} \\
& \mathrm{EtNiX}+\mathrm{BF}_{3} \rightarrow \mathrm{EtNi}+\mathrm{XBF}_{3}-
\end{aligned}
$$

この $\mathrm{ENi}^{+}$が安定でしかも高い活性能をむつのである. シス重合が起こるのはずっと後の大学の研究でわかった が，ポリマー末端から2番目のユニットの二重結合が二 ックルに配位しているためである。

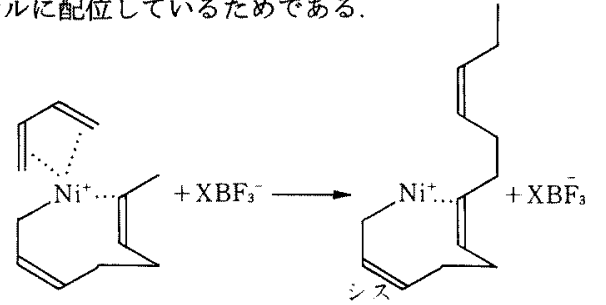

なぜならこの触媒でスチレンを共重合させると，スチレ ンと並んだブタジェン単位のシス選抧性は非常に落ちる ことが連鎖の NMR解析でわかったのである.スチレン が前にくると配位(これを back-biting coordination と呼 んだ)ができず，したがってポリマ一末端は環状となら ナ゙トランス型になってしまらのである。
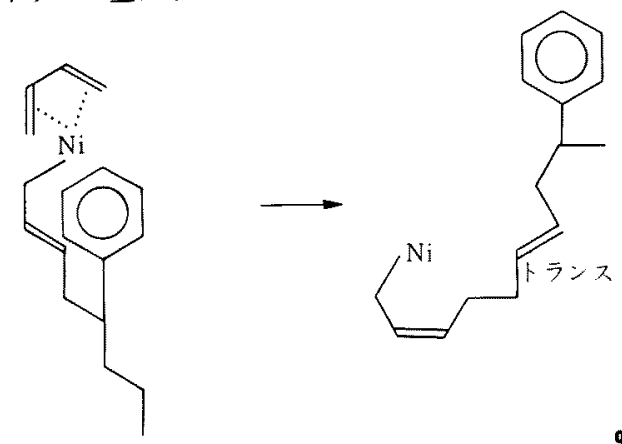
こらいってしまえば，この研究はいかにも簡単である が，発見までの探索，発見後の仕上げ，機權の解明など 実に多く人達が参画し，できた成果である：この方法は その後日本合成ゴムで国産化されるが，英，東独更にア メリカのグッドイヤー社などに技術輸出され，今日では 世業的工業になっている，その後わかったが，イタリア ではコバルト系でやはりシスポリブタジエンをつくる特 許を出しており，この二つの特許はともに成立してい る.筆者のバック配位説は，1975年のマドリッドの国際 高分子会議の招待講演で発表した．オレフィンの重合で は負触媒であるニッタルやコバルトが，どうしてジオレ フィンでは良い触媒になるのか，その理由はわかららな い，近年ウランを用いる触媒がイタリアで，ユーロピウ ムなどの希土類を用いる触媒が中国で発見され，シス含 量がさらに高いので興味をよんでいる。こうしてみると 負触媒といら文献があっても，それと触媒とは紙一重だ といらことになる、私はいつも文献を読んでは反対の事 の可能性を考えるよらになった.

シスポリブタジェンについては思い出はつきない，亡 くなられた松平信孝氏や，前田哲郎氏は私の生涯忘れる ことのできない先菲，心の友であった．日本合成ゴムの 勝本社長にも現在御厄介になっているし，ブリヂストン タイヤの高松哲也氏，元ブリヂストンにおられた植田賢 一氏，元日本合成ゴムの下里錠次氏ら今も肝胆相照寸友 である，日本合成ゴム秼相談役，川崎京市氏には，院に 日向に援助していただいた，私はよき先䧳，友人に恵れ たと心より感鶕している。

\section{4. 交互共重合ゴム}

定年までの7年間は忙しかった，学術会議会員になっ たり，国際会議への招待も多く毎年海外一出かけた。 して激しい大学紛争に見舞われた．何とか定年までに後 世に残すような大きな仕事をしてみたいとの焦りでいっ ぱいであった.この閒に二つの交互共重合ゴムの研究が できたのはせめてもの慰めであった，当時, ブロック共 重合全盛であったが，これと対照的の交互共重合は，ゴ ムとして面白いのではないかと考え出したのは十数年前 である．石油学会の関西講演会でむ話をしたことがあ る、しかし，交互共重合といらとスチレンやブタジェン と無水マレイン酸との交互共重合ぐらいしかなかった. プロビレンとブタジェンとが交互共重合できると，構造 は異なるがメチル基の数ではポリイソプレンと同じるの ができるはずで，ゴムとしては面白いのではないかと考 えた.これらのオレフィンとジオレフィンとは交互はお
ろか共重合もむずかしいと思われた. チーグラーの配位 重合ではジオレフィンの方が配位しやすいからである. 当時, 丸善石油加性川崎明裕氏, 中庭幹雄氏ら大勢の研 究員を大学に派遣してもらい，共同研究を始めようとし ていたが, 大学紛争が発生し, 企業反対といらわけで仕 方なく引き揚げてもらい，そのかわり京大出の平井隆一 君が正式に博士コースを受験し，大学院生として研究す ることになった。 もち論, 企業の研究ではなく,純然たる 学術研究として交互共重合の可能性を研究していった. 実は Natta の古い研究の中に，エチレンとブタジェンの 共重合の研究があり，大部分ホモポリマーの混合物であ るが，これを抽出分離していくとトレースではある゙交 互共重合物があると記載されている，しかし，少量です あるといらことはそれをつくり出す触媒種があることを 意味している，それは何だろらかと，大学と丸善石油と 雨方で研究していった. 半年か 1 年ぐらい経ったころ, 偶然, $\mathrm{VCl}_{4}$ と $\mathrm{Et}_{\mathbf{3}} \mathrm{Al}$ の超低温での混合物を熟成しない で使ってみたところ, 半固体状の重合体中の交互共重合 が著しく増加し，50\%に達していることがわかった. チ ーグラー触媒は通常, 常温で混合し, 更に $40^{\circ} \mathrm{C}$ 以下゙熟成 してつくるのである。すなわち触媒種を会合させたり結 晶化して活性化し，また立体規則性制御能力を高めるの である．例えば $\mathrm{TiCl}_{4}-\mathrm{Et}_{3} \mathrm{Al}$ 系ではこのとき $\mathrm{TiCl}_{3}$ がで き，これが結晶化して，プロピレンのイソタクト重合を 起こすのであるし，始めから固体の $\mathrm{TiCl}_{3}$ を用いて触媒 をつくる方法む開発されてきた，してみると螌媒の会合 や結晶化を起こさせないようにすると，交互共重合によ いことになる，触媒の詳細な研究を行い，電位滴定でバ ナジウムの原子価を調べたり，ESRでバナジウムの会合 状態など調へ，結局 $\mathrm{V}^{2+} か \mathrm{~V}^{3+}$ が弱く会合したものが触 媒種で，これがモノマーと反応して会合が解け，配位座 数がコントロールされたものであると推定し, 次のメカ ニズムを提案した.

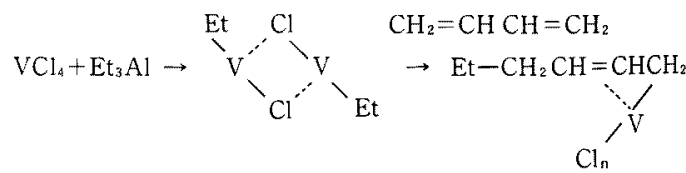<smiles>C=C(C)CCCC=CCC(C)C[Y](Cl)(Cl)C=CCC</smiles>

すなわち，ブタジエンが一般的に優先配位するが，生長 末端が既にブタジェンのときは，その二重結合が更に゙ 
ナジウムにルーアリル配位しているので，空の配位座が少 なくなり，ブタジエンの二座配位ができずプロピレンの 一座配位が起こるといら考えである。これはオレフィン， ジオレフィンの誘導体を数多く調べ，この考えに合うこ とを確めた、生成ポリマーをオゾン分解して分析してい くやっかいな方法で，京大と丸善石油の丸山功君が調べ あげていった。同し頃，丸善の研究所でも研究が進んで 招り，重合度を充分高めるすぐれた触媒を数多く発見し ていた．また，パイロットプラントで数十キロのゴムを 試作したが，優れた機械的性能をもち，天然ゴムに似た 性能を示すことを見出した，加硫物を延伸すると交互構 造の高い規則性のため，配列して非常に高い強度を示す のである.

これらの研究は，1970年のボストンの国際高分子シン ポジウム招待講演で報告したので，一躍世界中の注目を 集めることになった。

交互共重合についてはこれより少し前にアクリルニト リルーブタジェン交互共重合に成功したが，これは全く 異なる触媒系である，当時，塩化ビニルにプロピレンを 共重合しようとして竹田凱光君やブリヂストンタイヤか ら来ていた伊勢田君, 芳賀君らに $\mathrm{SnCl}_{4}-\mathrm{Et}_{3} \mathrm{Al}$ 系の研究 をしてもらっていたが,これはランダム共重合であった。 折しも住友化学の弘岡正明君が，オレフィンとアクリル エステルとを共重合するときに，アクリルェステルを当 モルの $\mathrm{Et}_{2} \mathrm{AlCl}$ で錯化しておくと, 得られるポリマーが 交互構造になるといら，興味ある報告をJ. Polymer Sci. に出した.これはその後，世界的な反響を呼ぶすばらし い仕事である．早速，この方法をブタジェンーアクリル ニトリル系に応用してみると，なるほど交互共重合する が，かなりのゲル化反応が起こる．錯化剂のアルミニウ ム化合物のカチオン重合性が高いので，架橋反応を起こ しているのであろらと，錯化剤を減らす方法がないもの 功と, 前の $\mathrm{SnCl}_{4}-\mathrm{Et}_{3} \mathrm{Al}$ の経験加ら，種々の遷移金属成 分を少量加えてみたところ， $\mathrm{Et}_{2} \mathrm{AlCl} の$ 量を1/100以下に 下げることに成功し，高い活性でしかもゲル含量がなく なり，可塑性の高い交互共重合のニトリルゴムを得るこ とができた，例えば，アクリルニトリルに対して $5 \%$ の $\mathrm{Et}_{2} \mathrm{AlCl}, 0.01 \%$ VCl で高い活性の触媒ができ，錯化 剂の $\mathrm{Et}_{2} \mathrm{AlCl}$ は循環してモ/マーを錯化していくことが わかった，錯化風の20倍のポリマーができるからであ る.この触媒系は成分組成からチーグラー触媒に似てい るが，重合機棈は全く買なっており，錯化したアクリル ニトリルにブタジェンが更に会合し，電荷移動錯体を形 成していることを触媒系の NMR，米点降下，反応速度
解析から証明した.この時分になると研究機器も進歩し ており，これらを充分に駆使することができた。この交 互共重合ゴムも，延伸により高度に配列し，著しく高い 强度を示すがゴムとしては充分な柔軟性を示す. $T_{g}$ む ンダムゴムよりかなり低くなる，工業化が充分検郡され たが，アクリルニトリルの含量が50\%に限定されるため 一般用には問題があり，工業的規模にするには困難があ ることがわかって，春現しなかったのは残念であった。

この交互共重合の研究はその発想, 計画, 研究が最も 理路整然と行われたものであったが，工業化できなかっ たことを考えると，学術研究だけでなく工業化研究には 更に多くの要素のあることを知らされた。

交互共重合に関連して一つつけ加えたいのは，アセチ レンとブタジェンの錯体共重合のことである。これは共 重合ができれば二重結合ではさ惊れた活性メチレンを含 み，桐油のよ5に空気硬化性の塗料ができるだろらと考 えた.

$\mathrm{CH}_{2}=\mathrm{CHCH}=\mathrm{CH}_{2}+\mathrm{HC} \equiv \mathrm{CH} \rightarrow\left(\mathrm{CH}_{2} \mathrm{CH}=\mathrm{CHCH}_{2} \cdot \mathrm{CH}=\mathrm{CH} \cdot\right)_{n}$

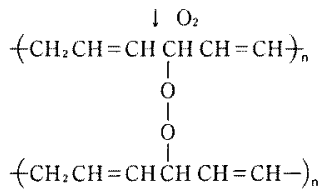

問題は触媒であるが，Ti系などのチーグラ一触媒を用い ると，真黑の粉末ポリア七チレンになってしま5。もっ とも，当時東工大の白川氏の研究の上5にシート状のポ リアセチレンができればまた别の意味があるが，この研 究の目的は共重合であった. しかし，このよ5な研究は やればできぬはずはないと思い，他の逗移金属を調べて みたところ、ニッケル系を用いると其重合し，淡黄色の 半固体，油状のポリマーができることがわかった，ブリ ヂストンから研究に来ていた川越君らの研究によるもの で，同君の学位論文になった。このポリマーは，NMR

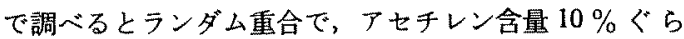

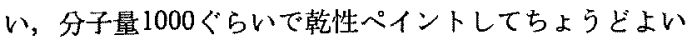
くらいの性質をもっているので，私の京大退官後，日本 ペイントで更に詳しい研究がはじまった．やってみると いろいろと新しいこともわかってきた，奉験条件によ り，黒色の金属ニッケルの微粒子が出てきて，重合活性 が弱るのと生成物から除くのが困難になる，しかし，偑 然の機会に装置中に水分が浸入し，この現象が留まるこ とを発晃した，水を加えて詳細な研究が行われ，次のよ らな結論に達した。この重合では当然,アセチレンユニ ットが末端に来る。すなわち， 


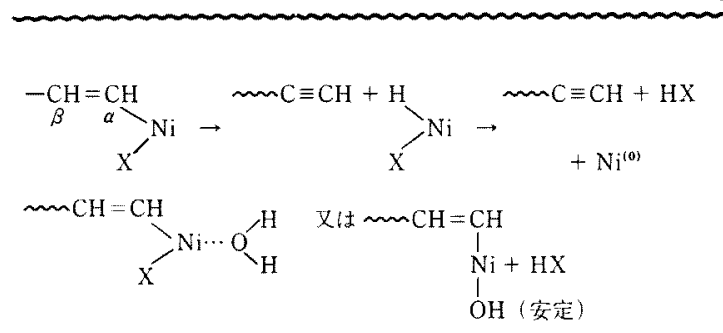

このとき $\beta$ 位の水素が引抜かれ $\mathrm{Ni}$-ハイドライドがで き，更に還元されて金属ニッケルができやすい，水があ れば配位したり置換したりして，脱水素が起こりにくい のである，遷移金属触媒に水分が非常に重要であること は, 以前のジェチル亜鉛一水系の触媒でいやといらほど 知らされているのに、これに気がつかなかったのはらか つであった. いつまでも偶然にたよっているようなこと では本物ではないなあと慨嗼した，も5一つの発見は架 橋風の発見である，空気酸化で硬化するが，速度が早す ぎて厚く塗ると表面のみ硬化し，しわがよってくる。こ れを防ぐには，逆に酸化倣をあらかじめ混ぜておけばよ いといら考えが起こるが，紫なる過酸化物では効果がな い.これも日本ペイントの研究陣が発見したが，二官能 性の過酸化物，例えばテレフタル酸過酸化物を用いる と，非常にらまくいく，単なる酸化剂ではなく架橋剤に なっている.このよ5に化学はまだ経験や偶然によって 進展していくものであると痛感した.

\section{5. ゴム物性の研究}

ゴム物性の研究は，もともと合成よりも物性のほらか゚ 私の好みに合っていた，戦時中の合成ゴムプラントで む，できてくるゴムは可塑性が悪く，ロールでもなかな か練れないので弱った経験がある、ロールにかけてもパ ラパラで，巻きつかず耳が白くなる，長く練っていると やっと透明なゴムになるが，この現象を見ているとゴム 分子の変化がわかるよちな気がしてくる，ゴムの粘弾性 は戦後初めて外国雑誌で知った，戦後始めた富久宏太郎 君の可塑度の研究は前に述べたが，助手をしていた西田 政三君とはゴムの膨潤や加硫反応の解析を行った．同君 は器用な人で、ゴムの研究は何でもやってのけた。 亡く なった学生の岩崎忠雄君は膨潤圧を測るため $3 \mathrm{~m}$ の水銀 柱をつくって調べ，浸透压の Ostwaldの式を変形した理 諭式を尊いた。しかしこの実験はやっかいで，ガラス管 の水銀柱が折れて水銀が流れ出したりして大変だった.

戦後の 5 年ぐらいは混乱と食糧のひっ迫で，身心とも 参っていたが，学問的好奇心は郋勢であった，その時の 発想の主なものにラジカル反応性の研究と擬絧目論コム
物性の二つがあり，どちらむゴムに関倸している，ラジ カル反応性は，有機化合物の熱分解のデータがたくさん 発表されており，それから推測できる。結合 $\mathrm{AB}$ の解離 エネルギー $D_{A B}$ を集めていくと，極性の強いものほど大 きく，次のような経験式が成立つことに気がついた。

$$
D_{A B}=J_{A}+J_{B}-e_{A} e_{B}
$$

$J_{A}, J_{\mathrm{B}}$ はラジカル $\mathrm{A}, \mathrm{B}$ に特有な值で共有結合性, $e_{A} \ell_{B}$ はA，Bラジカルの相互作用で，極性の反対の場合は吸 引で，極性の同じ場合は反発であり，電気の場合と似て いるので, 静電気モデルなどを考えて「化学」に連载し た.この式を出すためには，数百に上る解離エネルギー のデータ集め， $J_{A}, J_{\mathrm{B}}$ を決めてはまた直し，1年ぐら いかかった，実はこの式は Pauling の式から導かれるこ とにも気がついた. Pauling は，無機化合物の解離で, $D_{A B}$ 汢同一元素の結合の $D_{A A}$ と $D_{B B}$ の算術平均より常 に大きく，その差は電気陰性度 $\chi_{A}, \chi_{B}$ の差の 2 乘にな ることを示した.

$$
D_{A B}=\left(D_{A A}+D_{B B}\right) / 2+\left(\chi_{A}-\chi_{B}\right)^{2}
$$

この式の右辺の第 2 項を展開して,

$$
D_{A B}=\left(\frac{D_{A A}}{2}+\chi_{A}^{2}\right)+\left(\frac{D_{B B}}{2}+\chi_{B}^{2}\right)-2 \chi_{A} \chi_{B}
$$

と書けるが， $J_{A}=D_{A A} / 2+\chi_{A}{ }^{2}, J_{B}=D_{B B} / 2+\chi_{B}{ }^{2}$ とおく と筆者の式になる、このよらな式が有機物でも成立して いることは，ラジカルの電気陰性度を評価できることに なる. 有機イオン反応で有名なハメット則とい5のがあ るが，置換基定数 $\sigma_{A}$ と $e_{A}$ とが平行していることもわ かった，式(1)を用いてラジカル反応性の議論もできる. 詳細は省くが， $J_{A}, e_{A}$ がゴム用薬剤の性兵を議論する のに有効な事もわかってきた. C-C 結合は $D_{c-c}=80$ $\mathrm{kcal}$ で $J_{C}=40 \mathrm{kcal}, e_{C}=0$ で極性がないが，C-O では $D_{C-o}=70 \mathrm{kcal}, e_{0}=-7(\mathrm{kcal})^{1 / 2}$ でかなり極性が効いて いる. 過酸化ベンゾイルでは， $D_{0-0}=35 \mathrm{kcal}, e_{0}=-7$ $(\mathrm{kcal})^{1 / 2}$ でかなり反発が働いている. 重要なのは $J_{A}$ の值 でここれが大きいラジカルは強い結合力をもっており， ゴムから水素を引き拔いてしまい架橋剤になるが，ヨー ドのラジカルは Jが小さく結合して安定化する. 硫黄の ラジカルはJが中くらいで引き抜きと再結合の両方の性 質をもち、ラジカル連銧移動反応を引き起こしやすいと いら結論になる. 対象がゴムでなくビニルモノマーで は，Jの大きいものは重合開始剂，小さいものは停止剤， 中くらいのものは連鎖移動剂になる。この研究は, 住友 化学汃ら来た寒川誠二君の学位論文にもなった. しかし これらの研究での最む大きい収護は，阪大の井本稳先生 との親交が媣まったことである. 井本先生とはそれ以前 
加らおつきあいし，大阪工試の井上良三さんと戦後三 人で持廻りの雑誌会を何回もやり，元の大工試の大仁本 町の焼跡を訪問したり，ベッドが天井からブラ下がって いる井本研究空を訪九た。井本先生もゴムのしゃく解剂 の研究をしておられ，私とは学問的には見解が衝突した. 井本先生は実に人の好い方で私のしつ上うな質問でも怒 られた顔をされたことは一度もなかった，実はゴムしゃ く解の研究のむとは，イギリスの RAPRA の Watson 教授の先駆的な研究に発しており，15年ほど前，マンチ ェスター大の Treloar 教授の退官記念に招待されたとき に枋目にかかり，シュルスベリーの研究所まで車で連れ ていってもらったことも思い出す.

コムの研究を話す私が，最む大事な人である山下晋三 君のことを忘れていたのは申しわけない，余りに身近な 人だったのでっい書き忘れていた. ゴムの研究で山下君 とは一心同体，同君が独立して京都工芸繊維大の教授に なられるまでの15年間の私のゴムの研究は，彼との共同 研究であった，彼は優れた勘と判断力をもち，何でもや ってのける強い精神力の持ち主で,私の気持ちを把握し，

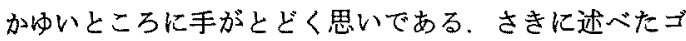
么用薬風の研究や，活性充てん剤をどんどんやってのけ た. 私が退官後, 最後にやるらとしているゴム物性理論 への興味は，彼によって引き起こされたものである。

る5一人，私の尊敬する協力者恃笛野高之君である。 新制の第 1 回の卒業生であるが，彼は全く天才的な数学 的才能の持主である。 ユタ大の H. Eyring 教授のとこ ろへやり，反応速度論，量子化学を勉強してもらった. 帰ってから助教授になって，私の仕事を手伝ってもらっ た.丁度プリンストンから私の所人留学にきた R. Shelden 君と共重合理論，不斉重合理論を組立てた。触 媒が $d$ と $l$ 対掌体になっている触媒の規則性制御のモデ ル理論をまたたく間につくり上げてしまった，阪大の教 授に栄転したが，いつかもう一度教えてもらいたいと思 っている. 私の研究空には多くの秀才が集まってきて, 笛野君のほかに, 諸熊圭治君や中过清君など量子化学で よい仕事をしているが，早くから私は彼らが好きな道一 進むよ5，福井謙一教授の研究室人推薦した．私は若い 方々に多くの研究室を遍歴することを奖めているが，昨 今注どの研究室も閉鎖的で䋥張根性が強過ぎて困ってい る.

最後に私の最近の仕事のことを書いておく、いま，私 はゴム物性論の仕上げに忙殺されている，擬網目理論を 考え，1955年にJ.Polymer Sci. に最初の論文を投稿した のは，30年も前のことである(図6)，退官後は実験はで

\section{INTRODUCTIN}

The flow pluthomenon of liquids was iutspreted by Eyringt as a rate process involving the thermal motion of molecules. His conception is based on the hole theory of liquids, which is applicable to the study of the viscosity of high polymers, ${ }^{2}$ but which fails to explain their elastic properlies. As an alternutive conecpt of the viscoulastic property of high polymers, the author presents a pseudo-rubberlite model in which a network structure arising from van der Waals' forces by twrest the polar groups of the adjacent linear polymers is assumed. Figure 1 shows the adjacent polar groups in neighboring polymer molecules lorking the adjacent segments (of the polymers) in a sense similar to crosslinks in vulcanized rubber.

Such pseudo-crusslinks, however, are not as permanent as ordinary diential erosslinks. The separation and recombitution of the segments take place continually. In other words, the crosslitiks migrate from plase to place, maintaining an equilibrium number of links at a given temperature. The separation and recombination of the segments are also rate processes like chemical reactions, but depend not only on the thermal motion of molecules but also on the external mechanical work done on the sample. From these concepts, the strain retardation or the stress relaxa-

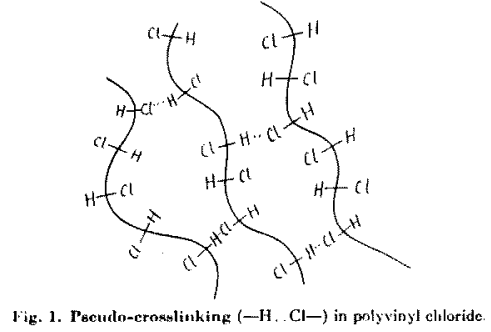

193

図 6 J. Polymer Sci (1955) に公表した擬網目理論 の最初の論文

きないが，理論ならできると思い，この仕事を再開し た. 掓絧目とは高分子のからみ合いを会合の上5に取り 扱い，熱力学上反応速度論で高分子固体や濃厚溶液の性 質を考えようというもので，高分子のガラス転移点，粘 性流動点, 緩和スペクトル，クリープ，ゴム弾性などの 複雑な現象を解明するむのである。バネやピストンの組 合せによる現象論と異なり，化学と直結していると考え ている，最近はゴムの破壃現象の解明むできるようにな った.これで一つ勝負をしたいと思っている，愛知工大 の岡本弘教授のグループとの共同研究で，実験も進んで きた，理諭ができると，実験的にもいろいろ面白い発想 が可能になる．末端にイオンをもつスターポリマーや， 逆に中心にイオンクラスターをもつスターポリマーをつ くり，新しい合成ゴムになることも発見し，今度のヨー ロッパ旅行にもって行こ5と思っている. 水ガラスを相 間移動触媒を用いてクロロホルムに溶けるよ5にして， 新しい充てん昘の開発研究も進んでいる，人生の終りに なって㜔けぽっ杭に火がついたようなもので，いい気な もんだと人はいらであろら。しかし，私には楽しいもの である。

こらしてみると研究むしょせん人々との交流である。 よき師，先輩をもち，親切な学会の友人，そして研究を 支えてくれた多数の学生諸君を思 らと，何時む楽しい回 
想に精気がよみがえる，時々，趣味は何ですかと閵かれ るが，私はいつも“科学のロマンだ”と答える。この果
てしない科学の舞台ほどすばらしいものはないと思って いる.

日本ゴム協会出版企画委員会編・日本ゴム協会発行

\section{ゴム技術の基礎}

\section{A5判 本文350ページ}

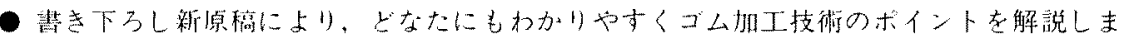
した。新入社崱の教青用テキストとしても樶適です。

\section{主 要 目次}

I ゴム基本特性 ゴムの構造と特性ノゴムの加工科学/架橋ゴムの分子構造と特性

II 原材料 原料ゴム/配合剂/補強材料

III ゴムの加工 基礎工程／成形加工 /のり引き，浸せき加工／加硫工程／接着加 工 仕上げ加工

IV 加硫ゴムの性能と配合 機械的性質と配合 /機能的特性と配合 /特殊性能と配 合 /加工性と配合/コストと配合／実用配合例

$\mathrm{V}$ 試験方法 試験と標準化/未加硫ゴムの物理試験方法 /加硫ゴムの物理試験方 法 $/$ 化学試験方法

VI ラテックスの加工技術 ラテックスの基本的性質/原料ラテックスと配合薬品 /基本配合処方のたて方 /配合操作 / 基本的製造加工方法

付 録 SIと従来単位との換算率/ゴム物理試験に用いられる量記号

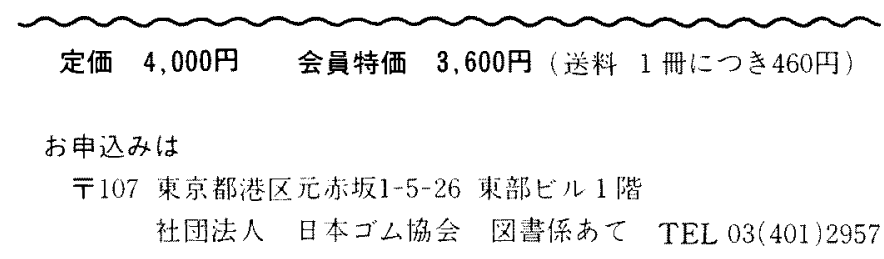

